\title{
Campaigning for utilitas: style, grammar and philosophy in C. Iulius Caesar
}

Andreas Willi

\section{INTRODUCTION}

C. Iulius Caesar is not a name that readily springs to mind in the context of an inquiry into the relationship between 'colloquial' and literary Latin; for "Caesar is incomparably the most "correct" of classical authors, if by "correct" we mean that he observes the "rules" of Latin orthography, grammar and word-order that would later become standardised by Palaemon and others' (Hall 1998: I8). Caesar's linguistic self-discipline, which famously restricts the vocabulary of the Bellum Gallicum to less than 1,300 lexemes, is so thorough that it even affects and excludes forms, words and constructions which can hardly be called 'colloquial' if this term is taken as the opposite of 'literary'. ${ }^{I}$ However, if we admit that colloquial Latin can also be taken to refer to 'the Latin used conversationally by the upper . . . classes during the Republic' (Dickey, this volume p. 66), in other words be equated roughly with what ancient theoreticians referred to by terms such as cottidianus sermo (Rhet. Her. 4.I4; cf. Ferri and Probert, this volume pp. I4, 39), then Caesar might even be called the most colloquial of Latin authors: there is little in his writings which could not also have been said, without much stylistic effect, in a standard upper-class conversation of his time. All the more, though, the inclusion of a chapter on Caesar in this collection might seem pointless: for whether we call nothing or everything 'colloquial', the lack of substantial diastratic differentiation in the primary material provides little scope for illuminating comments. $^{2}$

\footnotetext{
${ }^{\text {I }}$ Cf. e.g. the avoidance of the third person plural in -ere, shared with Cicero (E. Löfstedt I9II: 36-9; Leumann 1977: 607-8 with literature), of the genitive plural deum (Pascucci 1973: 490) or of the genitive of quality with third-declension adjectives (E. Löfstedt I956: I.I55-62); on the selection and number of lexemes (excluding names and technical terms) see Eden 1962: 94-8, Pascucci 1973: 493-5 and Hall I998: i7.

2 This statement does not imply that there is no stylistic variation in the Bellum Gallicum and the Bellum civile (cf. E. Löfstedt I956: II.307-8; Eden 1962: II3-I5), only that nothing which we do
} 
Our present focus will therefore be different. Instead of searching for marked (non-) colloquialisms in Caesar's writings, we will ask why he adopts such a smooth style and what this tells us about his (and some of his contemporaries') ideas on the relationship between colloquial and literary Latin. If we had only the Bellum Gallicum and the Bellum civile, such an endeavour might yield little but empty speculation. Fortunately, however, we possess, in a fragmentary state, a primary source that has rarely been fully explored or, I will suggest, understood. Mainly this is because Caesar the general and politician tends to eclipse Caesar the man of culture and learning who, according to Cicero (Brut. 252, 26I), was not only one of Rome's foremost orators - second to none but Cicero himself (Quint. Inst. IO.I.II4) - but who had also reached this perfection multis litteris et eis quidem reconditis et exquisitis summoque studio et diligentia 'through extensive reading even of inaccessible and little known texts, through extraordinary and most careful learning'. The neglected source I am referring to is Caesar's treatise De analogia, the remains of which consist of less than three dozen short fragments mainly culled from ancient scholars and grammarians such as Gellius, Probus, Charisius, Pompeius and Priscian and nowadays accessible in the collections of Funaioli (1907: 145-57) and Klotz (1927a: 177-85, the text and numbering adopted here).

\section{DATE AND CONTEXT OF CAESAR'S DE ANALOGIA}

According to Suetonius (Jul. 56.5), Caesar wrote the two books of De analogia: in transitu Alpium cum ex citeriore Gallia conventibus peractis ad exercitum rediret 'while crossing the Alps when he returned from Cisalpine Gaul to the army after he had held courts of law'. This information, together with the fact that the treatise was dedicated to Cicero (Gel. 19.8.3) and should therefore postdate the reconciliation of Caesar and Cicero in $56 \mathrm{BC}$, points to a composition in the spring of 55 or 54 ; in the winter of 54-53 Caesar stayed with the army, and in the spring of 52 the revolt of Vercingetorix hardly left any time to spare during a hurried journey (Dahlmann 1935: 259). Moreover, Hendrickson (1906) has made a good case for the year 54 from reading some of the introductory words, which are quoted by the proud dedicatee (Cic. Brut. 253 = fr. I), as a reply to Cicero's De oratore of 55 BC:

read there was normally excluded from either (a) 'higher' prose (i.e. 'colloquial' $\sim$ 'non-literary') or (b) an educated conversation (i.e. 'colloquial' 'belonging to the sermo cottidianus'); it is risky to assert (b) even for a 'slip' like the third person plural perfect sustinuere and accessere in Civ. I.5I.5 and 3.63.6 (cf. Rosén 1999: 187-9). 
ac si < ut $>$ cogitata praeclare eloqui possent, nonnulli studio et usu elaboraverunt, cuius te paene principem copiae atque inventorem bene de nomine ac dignitate populi Romani meritum esse existumare debemus: hunc facilem et cotidianum novisse sermonem nunc pro relicto est habendum.

And even if not a few people have worked hard in theory and practice to ensure that brilliant ideas can also be brilliantly expressed - and we must admit that you, who are more or less the leading force and the inventor of this richness, have done a great service to the name and dignity of the Roman people - to master this straightforward everyday style must nowadays be regarded as a relic.

These words seem to react to De orat. 3.38 and 3.48, where Crassus refuses to dwell on the ability of speaking Latine and plane:

neque enim conamur docere eum dicere, qui loqui nesciat; nec sperare, qui Latine non possit, nunc ornate esse dicturum ... praetereamus igitur praecepta Latine loquendi, quae puerilis doctrina tradit et subtilior cognitio ac ratio litterarum alit aut consuetudo sermonis cotidiani ac domestici, libri confirmant et lectio veterum oratorum et poetarum.

For we do not try to make an orator out of someone who cannot speak; nor to hope that someone who cannot speak good Latin, will now be able to make elegant speeches... Let us therefore pass over the precepts of how to speak good Latin, which are taught at elementary school, strengthened by the more advanced systematic study of grammar or by regular exposure to everyday language at home, and finally corroborated by books and the reading of old orators and poets.

What is here referred to as Latine dicere and taken for granted recalls the unornamented 'simple style' characterised as sermo purus et Latinus in the Orator (79) and already described with the same term as in the above passages by the Rhetorica ad Herennium (4.I4: id quod ad. . cottidianum sermonem demissum est). It thus appears that Caesar wants to complement the De oratore, where Cicero failed to give adequate guidance because of his elitist attitude: in De analogia we are supposed to learn more precisely what Latine dicere means. Given this background, its dedication to Cicero makes perfect sense, and since we know from a slightly later letter by Cicero how keen he was at that time to learn about Caesar's opinion on his literary output (Cic. Q. fr. 2.I6.5), we may also hypothesise, with Hendrickson (I906: IIO), that 'Cicero himself would have forwarded a copy [of the De oratore] to Caesar at his winter headquarters in Cisalpine Gaul'.

\section{CONTENTS AND BACKGROUND}

If Caesar felt that knowledge of an unadorned facilis et cotidianus sermo the kind of sermo we do find in the commentarii - was something that 
could not simply be taken for granted but had to be taught, just as much as Cicero's ornatus, the question arises how he went about doing so in $D e$ analogia. How did he determine what was, or was not, admissible in the target style?

Most of the fragments are tantalisingly uninformative. Apart from the one already quoted (which is preceded by the statement that Caesar also held 'that the selection of words is the basic principle of eloquence', verborum delectum originem esse eloquentiae), only one is of a general nature. Unsurprisingly it is this one which was most often cited in antiquity. In Gellius' rendering it reads (fr. $2=$ Gel. I.IO.4): tamquam scopulum sic fugias inauditum atque insolens verbum 'you should avoid like a rock in the sea any word that is unheard of or unusual'. Nearly all the other fragments concern specific minutiae of Latin usage and grammar, such as the correct formation of various case forms ${ }^{3}$ (e.g. fr. 6: accusative plural fagos, not fagus; 8: accusative singular turbonem, not turbinem; ${ }^{4}$ 9: genitive plural panium, not panum; Iо: genitive singular die, not diei; II: nominative plural isdem, not idem; I6: nominative-accusative singular lac, not lact; 22: nominative singular pubis, not pubes/puber; 23: dative singular ornatu, not ornatui; 26b: ablative singular iubare, not iubari, despite $25 \mathrm{a}, 25 \mathrm{~b}$ and $26 \mathrm{a}$ on the ablative in $-i$ of neuters in -ar, $-e,-a l ; 27$ : genitive plural partum, not partium), the assignment of grammatical number (fr. 3: harena, not harenae) and gender (fr. I8: masc. crinis; 19: ntr. pollen), word formation (fr. 28: mortus, not mortuus; 29: ens as participle of esse), syntax (fr. I2: se vs sese) ${ }^{5}$ and orthography (fr. 17: genitive singular Pompeiii, not Pompei). ${ }^{6}$ Thus, despite the randomness of what is transmitted, it is clear that De analogia did not just establish, or argue for, abstract rules, but entered into a discussion of a wide range of concrete topics.

What is more difficult to say on the basis of these fragments alone is whether Caesar's main aim was to provide stylistic guidance in every major

\footnotetext{
${ }^{3}$ Fr. 3I (= Gel. 6.9.I3, on $e$-reduplicated perfects like memordi, pepugi, spepondi) may not belong to De analogia (despite Klotz 1927a: 185); no other fragment deals with verbal conjugation, and Fronto (p. 224.I5-I6 van den Hout) summarises the contents of De analogia as de nominibus declinandis, de verborum aspirationibus et rationibus 'about the declension of nouns, about the aspiration and regularities of words'.

4 The fragment (Char. p. I83.19-24 Barwick) must be corrupt when it compares caro, caronis (sic), but the usual correction to Cato, Catonis is doubtful in the light of phonemic restrictions on analogical pairings (cf. fr. 13, Siebenborn 1976: 72-5); a better reading would be carbo, carbonis.

5 Doubting the authenticity of the fragment (Char. p. I42.4-7 Barwick: sese in indirect reflexive usages), Klotz (I910: 223-39) observes that Caesar uses sese for emphasis; however, the theory in De analogia does not always fully agree with Caesar's practice (cf. \$8, Oldfather and Bloom 1927: 596-7).

${ }^{6}$ Klotz (1927a: 185) further suggests that Caesar may have codified in De analogia the superlative spelling -imus instead of -umus (cf. Quint. Inst. I.7.2I, Isid. Orig. I.27.15). Similarly, the question of initial /h-/ (cf. n. 3) was partly (though not exclusively: Catul. 84, Gel. 13.6.3 with Nigidius fr. 2I Funaioli) an orthographical one.
} 
area of uncertainty or whether the grammatical suggestions he made were introduced as (probably selective) illustrations of some overarching principles. A number of considerations suggest the latter. Firstly, the scopulum rule (fr. 2) would be unhelpful to anyone wanting to know, say, what the 'pure' dative singular of a $u$-stem noun like ornatus was: the problem was precisely that neither ornatu nor ornatui were inaudita atque insolentia verba (cf. Lomanto 1993: 667-70). Secondly, most but perhaps not all of the issues mentioned in the fragments appear to have been real cases of doubt - although we have to concede that we may never know for sure whether a genitive plural partum or a participle ens sounded as outlandish in Caesar's time as our lack of relevant attestations suggests; after all, the similarly awkward-looking nominative-accusative lact was used by Varro (Men. 26, L. 5.I04) and Pliny (Nat. II.232, 22.II6), and partum could be found in Ennius (Ann. $593 \mathrm{~V} .=600$ Sk.). Thirdly, and most importantly, the title De analogia itself points to something theoretically more advanced than a 'Primer of Good Latin'. It positions the treatise in the midst of a fierce debate among Hellenistic and Roman grammarians, orators and philosophers (cf. Dahlmann 1935: 265-7I).

This is not the place to discuss in detail the controversies between the socalled 'analogists' and their opponents, the 'anomalists' (cf. e.g. Siebenborn 1976: 97-109). In a nutshell, it may be said that the analogists stressed the regularities in grammar, by pointing out paradigmatically predictable patterns, whereas the anomalists highlighted any breech of such regularity principles and thereby questioned whether language was governed by anything other than mere convention; hence, some of their strongest evidence came from word derivation (e.g. Var. L. 8.56: Parmensis $\leftarrow$ Parma, but Romanus $\leftarrow$ Roma), synonymy (e.g. Var. L. 8.71: aedes Deum Consentium, but regular genitive plural deorum) and homonymy (e.g. Var. L. 8.63: dative $=$ ablative in some nouns, but not in others). Moreover, given the largely negative, empiricist and anti-theoretical thrust of their arguments, the anomalists' position had the advantage of simplicity and they could weaken that of the analogists further by stressing the latter's internal disagreements. Thus, whereas the Alexandrian grammarian 'Aristarchus, Varro says, thought that analogical word forms should be used, to the extent that common usage permits', his Pergamene counterpart Crates of Mallus may have been more fundamentalist, thinking 'that analogical forms ought to be substituted for forms in common use'. 7 Such a divergence between two analogical positions shows that we must clarify not only whether a

\footnotetext{
7 Blank (2005: 238), who shows that the older view, according to which Crates was an anomalist, is based on a misreading of Varro's De lingua Latina.
} 
particular figure was an analogist or an anomalist but also whether he adopted one or the other viewpoint in a prescriptive or a descriptive manner. For instance, from Varro's text it appears that the Stoic Chrysippus, who wrote three books $\pi \varepsilon p i$ ơ $v \omega \mu \propto \lambda$ ías in which he demonstrated similes res dissimilibus verbis et dissimiles similibus esse vocabulis notatas 'that similar things were denoted by dissimilar words and dissimilar things by similar words' (Var. L. 9.I), was nevertheless in favour of analogically correcting oblique forms on the basis of the nominative and vice versa (cf. Var. $L$. I0.59); in other words, he was descriptively an anomalist (accepting that irregularities are real), but prescriptively an analogist (trying to do something about them). ${ }^{8}$ People like Aristarchus and Crates, meanwhile, were analogists both descriptively (playing down irregularities) and prescriptively (with Aristarchus apparently being more ready to make concessions when analogy crassly contradicted common usage), whereas empiricists like Sextus had to be descriptive as well as prescriptive anomalists (cf. Sextus Empiricus, Adversus mathematicos I.I9I-3).

Returning to Caesar, his title De analogia clearly suggests an analogist attitude of some sort, and many of the fragments point to a form of prescriptive analogism grounded in the descriptive recognition of anomalism (e.g. fr. $3=$ Gel. 19.8.3 Gaius enim Caesar. . . in libris quos ad M. Ciceronem de analogia conscripsit 'harenas' vitiose dici existimat, quod 'harena' numquam multitudinis numero appellanda sit 'for Gaius Caesar finds in the books about analogy, which he dedicated to Cicero, that harenae is wrong, since harena "sand" should never be used in the plural'). ${ }^{9}$ However, the case of Aristarchus vs Crates (vs Chrysippus) shows that even within the world of prescriptive analogism there were various positions, and we must therefore still ask which one Caesar was taking.

\section{CAESAR THE POPUlist OR CAESAR THE NATIONALIST?}

Whereas the grammatical fragments of De analogia have largely been neglected in historical and literary scholarship, two articles published in recent years have attempted to integrate this material into a larger picture of Caesar as a statesman. Although they come to widely divergent conclusions, both of them assume that Caesar's prescriptivism is of the 'fundamentalist' type.

8 On Chrysippus see further e.g. Steinthal I890: 359-73 and M. Frede 1978: 7I-3.

9 The plural harenae was widely used, not just in poetry (e.g. Verg. Aen. I.IO7), but also in cultivated spoken and written language (cf. the context in Gellius, Liv. 22.16.4, Suet. Aug. 80, etc.). 
According to Sinclair (1994), Caesar had observed in his court-hearings how the provincials in Gaul struggled to master a 'Ciceronian' elite language based on Roman upper-class consuetudo. In order to win the support of these groups, he decided to remove the barrier to their social advancement by propagating a 'democratic grammatical agenda', in which ratio was paramount and consuetudo at best played a role of arbitration when ratio did not provide a satisfactory solution. Caesar's 'impulse' to subject the Latin language to systemisation would thus introduce the anti-libertarian principles of political thought informing the later Principate.

In contrast to this, Hall (I998: 28) concludes that imposing linguistic order on the world against the intrusion of barbarisms, and imposing political order on it against rebarbative tribesmen, are two sides of the same intellectual coin'. Here Caesar is not making 'democratic' advances to provincials, but promoting a 'Latin ringfenced against contamination by obvious rhetorical baggage or alien artistic ornament ..., a deliberately calculated expression of uncompromising Romanitas'. The creation of a pure, analogist Latin, the Latin of the Bellum Gallicum, is primarily to be seen as directed against foreign, especially Greek, influences: it is nationalist rather than populist.

There are obvious weaknesses in both of these readings. For instance, one might object to Hall that, while every attempt to set up linguistic norms has something potentially 'national' about it, to construct an anti-Greek Caesar is hardly more promising than to construct an anti-Greek Cicero. Having spent several years in the East and having studied with Apollonius Molon in Rhodes, Caesar himself used Greek freely in speech and writing, ${ }^{10}$ and he greatly admired Greek culture (cf. e.g. Suet. Vit. Ter. 7 on Terence as a dimidiatus Menander). The fact that De analogia (fr. 22) promoted the Latin declension pattern for Greek words and names (e.g. accusative Calypsonem, not Calypso) is just the unavoidable result of an analogist's mindset and need not have anything to do with nationalism. ${ }^{\text {II }}$ And as for Sinclair's views, we may wonder whether Caesar in 54 BC really needed the support of some poorly educated provincials as much as that of the Roman aristocracy and, more generally, if the publication of a style guide is the most promising way to amass a political following.

In our context, however, the main shortcoming of these readings is their unquestioned belief in Caesar's linguistic fundamentalism and, in

Io Cf. Caes. Gall. 5.48.4, Cic. Q. fr. 2.I6.5, Plutarch, Caesar 2 and 46, Pompey 6o, Suet. Jul. 82.2; see further Kaimio (I979: I30-I, 255-6), who even concludes from Plin. Nat. I Ind. XviII that Caesar wrote his De astris in Greek.

II For the discussions about this issue see further Var. L. I0.69-7I, Quint. Inst. I.5.58-64. 
connection with this, their disregard for the intellectual debate in which De analogia takes part. To start with, Cicero himself states that Caesar rationem adhibens consuetudinem vitiosam et corruptam pura et incorrupta consuetudine emendat 'by applying analogy corrects mistaken and corrupt usage by pure and incorrupt usage' (Brut. 26I). In other words, Caesar's analogy does not operate freely, overruling usage in the name of a greater good. According to Cicero, the result of a Caesarian correction is still in line with one form of consuetudo, which would not (or not necessarily) be the case if only ratio counted. Moreover, only such a mitigated form of analogy is in line with the scopulum rule, and Poccetti (1993b: 62I) is therefore certainly right when he states that a closer inspection of the fragments of De analogia reveals how Caesar did not blindly espouse the analogists' cause, but rather positioned himself in the midst of the 'complex cultural kaleidoscope' of a period which was strongly imbued with eclecticism. In Poccetti's view, the consuetudo-based scopulum rule acts as a final check against an exaggerated application of analogical principles: first, 'abstract' analogy establishes that $Y$ would be better than $X$, but if $Y$ is an inauditum atque insolens verbum, whereas $X$ is not, $Y$ must not be used out of respect for consuetudo. ${ }^{12}$

However, this is not exactly what Cicero is saying (cf. Dihle 1957: 193-4; Siebenborn 1976: III-I2). Cicero speaks of two forms of consuetudo, one vitiosa, the other pura. Hence, both 'good' $Y$ and 'bad' $X$ are anchored in consuetudo. What Caesar's analogy does is merely help to decide which one is 'good'; whereas what is outside consuetudo to begin with need not be considered at all since the scopulum rule is applied at the start, not at the end, of the selection process. ${ }^{\mathrm{I}}$ Caesar's analogism is thus as non-fundamentalist as analogism could possibly be, and with its restriction to cases of variatio within consuetudo, which foreshadows Varro's reconciliatory position, ${ }^{\mathrm{I}}{ }^{\text {it }}$ would have been equally unsuited for a populist and for a nationalist agenda. The uneducated provincial still had to know what options were

I2 Cf. similarly Leeman 1963: I57; Dahlmann 1935: 262-4 remains somewhat contradictory.

I3 In practice, De analogia may have overstepped these limits occasionally, for why should for instance a participle ens be 'correct' when consuetudo apparently knew neither this nor any competing form (fr. 29; cf. Collart 1954: I48 n. 3)? Note, however, that the matter certainly called for debate on a theoretical level: contrast potest $:$ potens $=e s t: X \rightarrow X=$ ens with abest $:$ absens $=$ est $: X$.

I4 Cf. Var. L. I0.74 on the analogia quae derigitur ad usum loquendi (i.e. the individual's analogy); Siebenborn 1976: 96-7 and Müller 200I: 200 and 195, after Collart 1954: 149-57, on the primacy of consuetudo in Varro (e.g. L. 9.2-3, 9.35, 9.114) and his differentiation of a consuetudo recta and a consuetudo depravatalmala (L. 9.II, 9.I8). Contrast the stricter attitude depicted in Var. L. 9.20 (verbum quod novum et ratione introductum quominus recipiamus vitare non debemus 'we must not shrink back from accepting a word which is new and established through analogy') and enacted by people like Sisenna (Cic. Brut. 259, Gel. 2.25.9; Rawson 1979: 343-5). 
available through consuetudo, and even the staunchest defender of Romanitas was given no means to prevent consuetudo from adopting 'un-Roman' elements.

\section{RATIO, NATURA, AUCTORITAS}

Now, if for Caesar analogy should operate only where different forms of consuetudo compete, it might be asked whether that does not make his analogism meaningless. After all, even an anomalist had to decide in cases of doubt and might therefore have conceded that ratio could usefully be applied here. ${ }^{15}$ However, ratio was not the only possible criterion available. According to a Varronian fragment (fr. 268 Funaioli), [Latinitas] constat . . his quattuor: natura analogia consuetudine auctoritate 'good Latin rests on these four criteria: nature, analogy, usage, and authority'. ${ }^{16}$ The relative weight given to each of these could vary, so that assigning the first rank to consuetudo still left open the possibility of deciding between competing forms of consuetudo with the help of either natura or auctoritas rather than analogia (ratio). In order fully to understand the implications of Caesar's position, we must briefly look at these alternatives in turn.

Varro's natura is a somewhat elusive concept (cf. Siebenborn 1976: 15I4). In the fragment cited, he exemplifies it by arguing that the use of a form scrimbo instead of scribo would simply be 'unnatural' (presumably because no-one ever uses or used scrimbo, nor would anyone postulate scrimbo for the sake of analogy), but the term also evokes the old discussion between

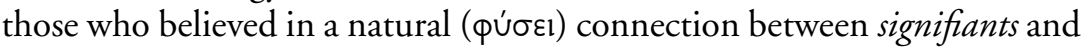
signifiés and those who held that signifiants were assigned to signifiés through an act of - potentially ${ }^{17}$ arbitrary and conventional - nomenclature ( $\left.\theta \dot{\varepsilon} \sigma \varepsilon l\right)$.

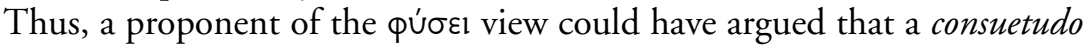
variant $Y$ is better than its competitor $X$ because $Y$ is closer to the 'inherent nature' of the concept denoted, as shown for instance through etymology.

There is one fragment of De analogia which leaves no doubt about what Caesar thinks of such naturalist theories of language (fr. $4=$ Gel. 19.8.7). Having established that caelum 'heaven', triticum 'wheat' and harena 'sand' should not be used in the plural, he asks his addressee: num tu harum rerum natura accidere arbitraris quod 'unam terram' et 'plures terras' et

is Cf. the anti-analogist voice in Var. L. 8.26, where the acceptance of variation is then preferred.

${ }^{16}$ Cf. Quint. Inst. I.6.I with a slightly different list; from Cic. Orat. 157 one might also add suavitas, i.e. 'euphony' (Siebenborn 1976: 154-5).

${ }^{17}$ Not all $\theta \dot{\sigma} \sigma \varepsilon l$ proponents believed in a purely arbitrary relationship of signifiants and signifiés: cf. n. 19 . 
'urbem' et 'urbes' et 'imperium' et 'imperia' dicamus, neque 'quadrigas' in unam nominis figuram redigere neque 'harenam' multitudinis appellatione convertere possimus?, 'Do you think it is due to the nature of these things that we can speak of one terra "earth" and several terrae, of one urbs "City" and several urbes, of one imperium "supreme power" and several imperia, but cannot turn the word quadrigae "horse-team" into the singular or the word harena "sand" into the plural?' The expected answer is 'No', and the viewpoint we are invited to share is unmistakably conventionalist. ${ }^{18}$

Turning to auctoritas, Caesar could hardly have put a similarly dismissive rhetorical question to his dedicatee. We remember Cicero's words in De orat. 3.48: praetereamus igitur praecepta Latine loquendi, quae. . libri confirmant et lectio veterum oratorum et poetarum (cf. above, \$2). For someone like Cicero, who was even prepared to accept the occasional archaism merely for the sake of ornatus (De orat. 3.39), auctoritas would have been a more obvious choice than ratio in deciding between competing variants (cf. Fögen 2000: 136-8).

\section{INVENTING EPICUREAN GRAMMAR AND STYLE}

To sum up the results reached so far, we have seen that (a) despite its title the De analogia assigned first rank to consuetudo, not ratio, in the relative weighting of possible criteria of Latinitas, and (b) the fact that ratio, not auctoritas (or natura), was placed second is itself worth noting, especially given the well-known traditionalist attitudes of large parts of the Roman establishment. We are now in a position better to define the place of Caesar's treatise - and with it, of Caesar's stylistic choices more generally on the intellectual map of the Roman first century BC.

What is most remarkable about (a) is its pragmatic, undogmatic, approach to language: it implies an empirical analysis of current consuetudo whilst recognising that consuetudo is not always uniform. Together with the unconventional stance adopted in (b), this yields a combination that is neither in line with Alexandrian grammar à la Aristarchus (where the basic procedures are theoretical rather than empirical) nor particularly close to the linguistic thinking in the philosophical schools most interested in such matters: Stoicism and (Neo-)Pythagoreanism. It is true that the descriptively anomalist position of someone like Chrysippus (above, $\$_{3}$ ) has an

I8 Cf. in this context also Morgan (I997) on Caes. apud Suet. Jul. 77 nibil esse rem publicam, appellationem modo sine corpore ac specie 'the res publica is nothing, just a name without substance and form'. 
intrinsic affinity with a consuetudo-focused empiricism, but a true Stoic would not have dismissed as absurd the idea that something in language 'happens by nature' (natura accidere); and similarly, a Pythagorean would

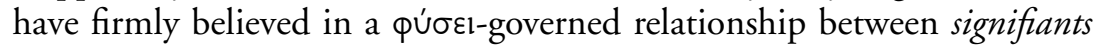
and signifiés, ${ }^{19}$ while being less ready to compromise on the imposition of analogy through respect for consuetudo.

Yet, there is one philosophical school with whose principles Caesar's unique combination of (a) and (b), and also his dismissal of natura as a factor in the shaping of language, tallies well: Epicureanism. Admittedly, Lucretius' Epicurean 'Bible' De rerum natura, also published in 54 BC, has little to say about language, except for a digression on its origin from animal sounds (Lucr. 5.IO28-90). In a sense, language has thus come about

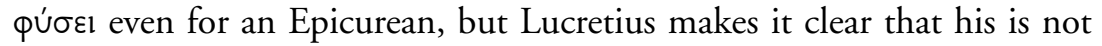
a púors origin which informs the actual relationship of signifiants and signifiés: instead, this relationship is governed purely by human utilitas, as demonstrated by a passage from Epicurus' Letter to Herodotus (75-6), where the author underlines the function of language as a tool for unambiguous, concise communication among groups of people who have come to an agreement about its use. ${ }^{20}$

Unsurprisingly this teaching fits in well with wider Epicurean theories about the world. According to these, the cosmos is governed by natural laws as a consequence of orderly atomic motion. However, because of the existence of the clinamen or 'swerve', which can make atoms collide unpredictably, there is no absolute determinism and mankind is able and invited rationally to apply its free will within the framework defined by the natural laws. Crucially, the fact that chance may sometimes shatter a rational plan must never discourage such rational action, for the ideal Epicurean will remain 'reactively creative' even in the face of adversity, his highest aim always being utilitas for the community.

Now, what has been described under (a) and (b) above constitutes a sort of parallel microcosmos. Consuetudo is the communal linguistic framework over which the individual has as little say as over the laws of nature, and it is subject to influences which make it unpredictable. However, within the framework set by consuetudo there is room for individual choices, and these must be governed by ratio because only ratio has the potential of optimising the usefulness (utilitas) of language as a communicative tool. If

I9 Technically, the Pythagoreans promoted the $\theta \varepsilon$ $\sigma \varepsilon l$ view, but since they believed in a name-giver with a superior insight into the nature of things, their position was ultimately similar to that of the Stoics (cf. Collart 1954: 259-60, 262).

${ }^{20}$ On these passages see now Atherton 2005; Verlinsky 2005; Reinhardt 2008. 
one disregards other functions of language, it is not useful, for instance, to retain a dative ornatu next to another dative ornatui.

It is this strictly utilitarian view of language which explains why Epicureanism traditionally had an uneasy relationship with the arts of rhetoric and literature. This was particularly obvious in the case of the (deliberately?) unpolished earliest philosophical treatises in Latin by Amafinius and Rabirius, ${ }^{2 \mathrm{I}}$ but even the Greek Philodemus, a friend of Caesar's family, who was interested in questions of literary style and perhaps more flexible in such things than many Epicureans, maintained that form and content should not be separated because style was primarily a means to an end. Thus, for a person with Epicurean leanings it would have been difficult to appreciate Cicero's De oratore with its emphasis on ornatus. A text like Caesar's Bellum Gallicum, on the other hand, which claimed to be nothing but an artless military report, would have been something of an ideal, even when in reality there was much art behind the artlessness.

\section{CAESAR AND EPICUREAN ROMANNESS}

We are now beginning to see an intrinsic connection between Caesar's linguistic theories and his literary style. Any Roman Epicurean should not only have aimed for a Caesarian style, devoid of ornatus while efficiently communicating facts, but also adopted a Caesarian view on what constitutes good Latin. For such an Epicurean, Latin, like any language, was essentially a means of communication, and therefore the community of its speakers - not their ancestors (auctoritas) or some abstract principle (natura) - had to define what was, or was not, admissible (consuetudo); but since any community may have its disagreements, a fair method of solving these was also required, and for this purpose nothing could serve better than ratio, the distinctive capacity of humankind.

So everything would fall into place if we could assume that Caesar's thinking about, and making use of, language was informed by Epicureanism. Fortunately, there are good reasons to do so, since Caesar's Epicureanism has been firmly established by other scholars looking at literary and historical rather than linguistic and stylistic evidence. ${ }^{22}$ The Epicurean's pragmatic approach to adversity and his 'reactive creativity' aiming at utilitas for the community provides the structural backbone of Bellum

${ }^{21}$ Cf. Cic. Ac. I.5, Tusc. I.6, 2.7, 4.6-7.

${ }^{22}$ See especially Rambaud 1969 and Pizzani 1993, e.g. on fortuna in the commentaries, Caesar's speech in Sallust's Catilina or the clementia Caesaris. 
Gallicum and Bellum civile alike. Whatever the political realities and propagandistic aims behind these texts (Rambaud 1966), their presentation is informed by philosophical principles - and we now realise, undoubtedly as Cicero did (Brut. 262), ${ }^{23}$ that they are also written in the utilitarian style that naturally suited those principles.

To Cicero, however, a philosophy whose highest good was utilitas must have seemed exceedingly primitive (cf. Pis. 70). Caesar, in turn, must have been aware of this disdain, for De analogia, in an elegantly oblique manner, set the issue straight. Its dedicatory sentence (quoted in $\$ 2$ above) presents Cicero as the inventor of a new Latin style, whereas Caesar himself acts as the advocate of an almost forgotten one. In Rome, where the mos maiorum was commonly acknowledged to be the most important social guideline, the latter, 'Caesarian', role was inevitably to be valued more highly. Moreover, the same sentence associates 'tradition' with the use of a facilis sermo - a facere-related, pragmatic, sermo - whereas the innovation focuses on thoughts (cogitata eloqui). Given the opposition facere vs cogitare, an attentive reader could not fail to remember that Rome's greatness was the result of acting, not thinking. Hence, the Epicurean linguistic pragmatism advocated by De analogia turns out to be the perfect embodiment of traditional Roman values, and any dissenting school of thought, however more sophisticated it may look, will only be the less 'Roman' for it.

\section{CONCLUSION}

It is time to conclude. At the outset, we observed that Caesar may be called both the most and the least colloquial of all Latin writers, since his 'Style without Qualities' excludes both what would have been heard only in ordinary conversation (e.g. vulgarisms) and what would never have been heard there (e.g. poeticisms). Among stylists, the latter restriction required a more explicit formulation than the former - hence the scopulum rule. In a wider sense, however, the scopulum rule could also be interpreted as an injunction against vulgarisms and the like; after all, in the context of, say, a general's report to the Senate a vulgarism too would have been an inauditum atque insolens verbum. If we believe Cicero when he suggests that De analogia was principally giving guidance in cases of doubt, we will probably best explain the occasional disregard for its precepts in Caesar's

23 Leeman (I963: I75-7), Brugnoli (I993) and Lomanto (I994-5: 53-5) stress the half-heartedness of Cicero's praise. 
other writings along these lines. ${ }^{24}$ As long as no educated person wrote mortus or partum in a formal text - however advisable their adoption might seem to an analogist - Caesar himself could not admit them in such a register because his readers would otherwise have 'stumbled' and the communicative flow would have been disturbed. ${ }^{25}$ In a speech to his army, however, things might have been different if the 'unusual' variants were widespread enough in oral Latin to be unmarked. ${ }^{26}$ Thus, Caesar apparently used the analogically regular, but otherwise less 'grammatical', active form frustrabo instead of frustrabor in addressing his soldiers (Caes. orat. fr. 9 Klotz). ${ }^{27}$

In a more speculative vein, we may finally ask what would have happened if Caesar's De analogia had made a more lasting impact. As it is, Cicero's De oratore won out, Cicero himself became the model of Latinitas, and auctoritas - including, ironically, Caesar's own auctoritas - got precedence over Epicurean consuetudo cum ratione. However, at least in theory the latter could have prevailed over standardisation, so that the gap between spoken/colloquial and written/literary Latin would not have become as wide as it did. Presumably, the Romance languages would still be what they are now, but we might not think of them as something distinctly different from Latin, for no 'classical' Latin would have come into being. And given all this, it might even be that in hindsight Caesar would have disapproved more of the 'archaisms' or 'poeticisms' allowed for ornandi causa by his highly respected dedicatee, Cicero (De orat. 3.39), than of the 'colloquialisms' and 'vulgarisms' used consciously or unconsciously by his less respected imitators, including the author of the Bellum Africum whose un-Caesarian style has been described so well by the dedicatee of the present volume. ${ }^{28}$

${ }^{24}$ For examples see Oldfather and Bloom 1927; Dahlmann (1935: 264) argues that Caesar's 'analogistische Theorie bezieht sich lediglich auf die Beredsamkeit', but the style of the commentarii is clearly informed by similar ideas.

25 On Caesar's respect for generic conventions see Adams 2005b: 74-7, after Eden 1962: 78-94 and Leeman 1963: 175-7.

${ }^{26}$ Mortus is attested in Pompeii (CIL IV 3I29; cf. also N-W III.529); on partum see $\$ 3$.

${ }^{27}$ Already found in Pl. Bac. 548 and Pompon. com. 79, and frequent in later Latin (Flobert 1975: 294), active frustro is likely to have been common in first-century spoken language. Similarly, $u$-stem datives in $-u$ were used by Caesar in speeches and in the Anticato (Gel. 4.I6.8, with Caes. orat. fr. 2 and Anticato fr. 5 Klotz), though perhaps not in the commentarii (Oldfather and Bloom 1927: 594-5).

${ }^{28}$ Adams 20o5b. 